\title{
Analisis perencanaan dan pengadaan guna menjamin ketersediaan obat di rumah sakit
}

\author{
Rafiastiana Capritasari ${ }^{*}$, Dwiky Ramadhani Kurniawati1 \\ ${ }^{1}$ Poltekkes TNI AU Adisutjipto, Yogyakarta, Indonesia
}

DOI: https://doi.org/10.29303/sjp.v2i1.71

\section{Article Info}

Received : 2020-12-08

Revised : 2021-01-29

Accepted: 2021-04-28

\begin{abstract}
Management of drug is one of the factors which contribute to the quality of hospital services. This study aimed at finding out drug planning in Pharmacy Unit of Adelia Surgical Hospital by using ABC analysis method. This research is qualitative descriptive study involving informants. Primary data were collected by interview with respondents and secondary data report of general drugs purchased period of May 2018 May 2019. The Result using ABC analysis indicate that there are $23(17,42 \%)$ kindof drugs in group A, 35 (26,52\%) in group B and 74 (56,06\%) in grup C. Group A if in the event of an excess or deficiency will couse harm to the hospital. ABC analysis method will effectively improve hospital drug consumption plan.
\end{abstract}

Keywords: ABC Analysis, Drug Procurement Planning, Hospital Management

Citation: Capritasari R, \& Kurniawati D.R. (2021). Analisis perencanaan dan pengadaan obat guna menjamin ketersediaan obat di rumah sakit. Sasambo Journal Of Pharmacy, 2(1), 32-36. doi: https://doi.org/10.29303/sjp.v2i1.71

\section{Pendahuluan}

Dalam Peraturan Menteri Kesehatan Republik Indonesia No 72 Tahun 2016 tentang Standar Pelayanan Kefarmasian di Rumah Sakit, disebutkan bahwa Rumah Sakit adalah institusi pelayanan kesehatan yang menyelenggaraan pelayanan kesehatan perorangan secraa paripurna yang menyediakan pelayanan rawat inap, rawat jalan dan gawat darurat. Pelayanan Kefarmasian merupakan pelayanan langsung dan bertanggung jawab kepada pasien yang berkaitan dengan sediaan farmasi dengan maksud mencapai hasil yang pasti untuk meningkatkan mutu kehidupan pasien (Kemenkes RI, 2016).

Instalasi Farmasi Rumah Sakit adalah unit pelaksana fungsional yang menyelenggarakan seluruh kegiatan pelayanan kefarmasian di rumah sakit. Standar pelayanan kefarmasian di Rumah Sakit meliputi standar : 1) pengelolaan sediaan farmasi, alat kesehatan dan bahan medis habis pakai, 2) pelayanan farmasi klinik (Kemenkes RI, 2016). Pengelolaan obat di rumah sakit harus efektif dan efisien karena obat harus ada saat dibutuhkan, dalam jumlah yang cukup, mutu terjamin dan harga terjangkau. Dalam Peraturan Menteri Kesehatan Republik Indonesia No 72 Tahun 2016, pengelolaan sediaan farmasi meliputi pemilihan, perencanaan, pengadaan, penerimaan, penyimpanan, pendistribusian, pemusnahan, penarikan, pengendalian dan administrasi.

Analisis ABC dikenal sebagai metode untuk membuat penggolongan berdasarkan pada peringkat nilai terbesar hingga terkecil dan terbagi menjadi 3 kelompok yaitu A, B dan C. Tujuan dari analisis ini adalah untuk mengetahui obat prioritas yang dikendalikan, baik dari segi perencanaan maupun pengadaannya (Siregar, 2003).

Hasil penelitian tentang perencanaan dan pengadaan obat di Rumah Sakit St. Madyang Palopo Provinsi Sulawesi Selatan menunjukkan bahwa pengendalian persediaan masih belum dilakukan secara optimal untuk mencapai efektifitas dan efisiensi. 
Hal ini dikarenakan belum terdapatnya formularium yang dapat dijadikan acuan dalam perencanaan pemesanan obat. Perencanaan obat tersebut belum memadai dikarenakan perencaaan obat hanya berdasarkan kebutuhan harian saja sehingga tidak sesuai dengan jumlah yang seharusnya dipesan, melainkan harus disesuaikan dengan anggaran yang ada (Humang et al., 2018). Hal ini sejalan dengan penelitian Kindangen, G.E, et al, 2018 yaitu apabila terjadi kelebihan atau kekosongan sediaan farmasi maka akan menyebabkan kerugian untuk rumah sakit sehingga perlu dilakuakn pengontrolan perencanaan pengadaan obat.

Berdasarkan permasalahan yang ditemukan dalam ketersediaan obat di Instalasi Farmasi Rumah Sakit, maka peneliti ingin mengetahui gambaran proses perencanaan dan pengadaan obat di Instalasi Farmasi Rumah Sakit Bedah Adelia.

\section{Metode}

\section{Lokasi dan Waktu Penelitian}

Penelitian ini dilakukan di Instalasi Farmasi Rumah Sakit Bedah Adelia Yogyakarta. Penelitian ini dilaksanakan pada bulan September 2019.

\section{Jenis Penelitian, Obyek dan Subyek Penelitian}

Jenis penelitian ini adalah penelitian kualitatif dengan pendekatan deskriptis analitik. Analisis yang digunakan adalah analisis penggunaan $\mathrm{ABC}$ dan skor investasi $\mathrm{ABC}$.

Objek penelitian ini adalah data sekunder berupa dokumen yang ada kaitannya dengan perencanaan kebutuhan obat di Instalasi Farmasi Rumah Sakit Bedah Adelia. Subyek penelitian ini adalah :

1. Pegawai Keuangan untuk memperoleh profil rumah sakit dan data-data yang dibutuhkan.

2. Apoteker sebagai Kepala Instalasi Farmasi Rumah Sakit dan seluruh staf farmasi yang dapat memberikan infromasi serta data-data perencanaan obat yang dibutuhkan.

3. Dokter yang mengetahui jenis obat apa saja yang akan dibutuhkan.

\section{Pengumpulan Data}

1. Pengumpulan Data Primer

Data primer diperoleh dari hasil pengamatan langsung serta melakukan wawancara. Selaku pewawancara dalam penelitian ini adalah peneliti serta yang terwawancara adalah informan (subyek pada penelitian ini).

2. Pengumpulan Data Sekunder

Data sekunder diperoleh dari data Instalasi Farmasi Rumah Sakit yaitu berupa data masuk dan keluar obat. Data yang didapat dari Instalasi Farmasi Rumah Sakit selanjutnya dikelompokkan berdasarkan analisa ABC.

\section{Analisa Data}

Analisa data dilakukan dengan langkah-langkah sebagai berikut :

1. Menghitung Nilai Pakai

a. Daftar semua obat yang digunakan selama periode Mei 2018 - Mei 2019

b. Masukkan kualitas pemakaian dan diurutkan dari pemakaian terbesar hingga pemakaian terkecil

c. Hitung persentase setiap item obat dari jumlah pemakaian total

d. Hitung persentase kumulatif setiap item obat

e. Obat dikelompokkan berdasarkan persentase.

Kelompok A dengan pemakaian 70\% dari keseluruhan pemakaian obat. Kelompok B dengan pemakaian 20\% dari keseluruhan pemakaian obat. Kelompok C dengan pemakaian $10 \%$ dari seluruh pemakaian obat.

2. Menghitung Nilai Investasi

a. Daftar semua obat yang digunakan selama periode Mei 2018 - Mei 2019

b. Masukkan jumlah pemakaian dan harga beli satuan sediaan terkecil

c. Hitung nilai investasi dengan mengalikan jumlah pemakaian dengan harga

d. Hitung persentase nilai investasi setiap item obat

Obat dikelompokkan berdasarkan persentase nilai investasi. Kelompok A dengan investasi $70 \%$ dari keseluruhan investasi obat. Kelompok B dengan investasi 20\% dari keseluruhan investasi obat. Kelompok C dengan investasi $10 \%$ dari seluruh investasi obat.

\section{Hasil dan Pembahasan}

Sumber daya manusia (SDM) di suatu organisasi merupakan salah satu faktor pendukung dalam kelancaran suatu kegiatan. Berdasarkan hasil wawancara peneliti dengan informan, diketahui bahwa saat ini sumber daya manusia (SDM) yang ada di Instalasi Farmasi Rumah Sakit Bedah Adelia untuk melakukan pengelolaan perbekalan farmasi yaitu terdapat tiga orang SDM yaitu satu orang apoteker dan dua oarang asisten apoteker. Perlu adanya analisis beban kerja untuk para tenaga farmasi yang akan berhubungan dengan perencanaan jumlah SDM sehingga tidak ada lagi pegawai yang bekerja double job (Kencana, 2016).

Dari hasil penelitian yang dilakukan mengenai proses pengadaan obat, berikut beberapa hal yang menjadi bahan pertimbanga, yaitu :

1. Formularium atau Standar Terapi di Rumah Sakit

Dari hasil wawancara diketahui bahwa Rumah Sakit Bedah Adelia sudah mempunyai Standar Terapi atau Formularium Rumah Sakit yang telah 
diberlakukansecara resmi oleh Komite Farmasi dan Terapi (KFT) maupun oleh pihak manajemen. Sehingga pengadaan obat dpat terkontrol terutama dari segi jenis obat yang telah disepakati untuk digunakan.

Komite Farmasi dan Terapi (KFT) adalah penghubung antara staf medis dan pelayanan farmasi terkait penggunaan obat untuk mencapai keamanan dan optimalisasi pelayanan (Ramadhan, R dan Sandi, I, 2014). Sebelum Standar Terapi atau Formularium Rumah Sakit disusun mengacu kepada Formularium Nasional. Formularium Rumah Sakit merupakan daftar obat yang disepakati oleh antara pihak manajemen, dokter, dan apoteker melalui KFT yang ditetapkan oleh Pimpinan Rumah Sakit (Kemenkes RI, 2016).

Pemilihan obat untuk masuk dalam Formularium Rumah Sakit memiliki beberapa kriteria salah satunya adalah obat yang terbukti paling efektif secara ilmiah dan aman (evidence base medicine) yang paling dibutuhkan untuk pelayanan dengan harga yang terjangkau (Kemenkes RI, 2016). Sehingga memberikan informasi obat yang lengkap untuk pelayanan medis. Formularium Rumah Sakit ini sebagai dasar dokter membuat resep untuk terapi pasien.

Menurut Yusmainita, 2005 yang tertuang dalam penelitian Suciati, et al. 2006 menyatakan bahwa dokter yang meresepkan obat diluar Formularium Rumah Sakit mengakibatkan pengadaan obat tidak dapat direncanakan dan diadakan sesuai kebutuhan RS. Sehingga dapat berakibat penumpukan obat yang kadaluarsa dan ketidaktersediaan obat yang diperlukan.

Faktor penyebab dokter membuat peresepan di luar formularium rumah sakit antara lain :

a. Obat yang dibutuhkan belum masuk dalam formularium rumah sakit

b. Kelengkapan obat yang sudah masuk dalam formularium rumah sakit belum tersedia sepenuhnya

c. Adanya pendekatan dari perusahan obat

Dalam usaha mencegah kekosongan obat, Rumah Sakit Bedah Adelia membuat kebijakan untuk melakukan peminjaman atau pembelian langsung ke rumah sakit dan apotek sekitaar yang telah menjadi relasi. Hal ini sesuai dengan amanat yang yang terdapat di Undang-Undang Kesehatan No 36 Tahun 2009 yaitu untuk menjamin ketersediaan obat dalam keadaan darurat, dapat melakuka kebijakan khusus untuk pengadaan dan pemanfaatan obat dan bahan berkhasiat obat.

Jika peresepan obat di luar formularium terjadi berulang untuk obat yang sama, Instalasi Farmasi akan emmbuat pengajuan ke KFT untuk dimasukkan ke dalam formularium. Selama proses pengajuan serta persetujuan oleh KFT, obat tersebut disediakan terlebih dahulu untuk menghindari pembelian di apotek luar (Suciati, S, et al. 2006).

\section{Pengendalian Anggaran}

Pengendalian persediaan obat di Rumah Sakit Bedah Adelia tidak terdapat perbedaan dan pemberian prioritas diantara semua obat. Pemberian prioritas hanya diutamakan pemesanannya karena anggaran terbatas seperti untuk obat life saving, obat anestesi atau obat-obat cito. Adapun untuk obat yang dapat disubstitusikan, proses pengadaan biasanya ditunda dahulu.

Metode pengendalian yang dilakukan di Rumah Sakit Bedah Adelia yaitu dengan cara petugas menghitung sisa stok yang ada pada setiap interval waktu tertentu dan membandingkan dengan sisa stok yang seharusnya (buffer stock). Jika didapatkan jumlahnya dibawah buffer stock maka dilakukan pemesanan kembali. Pemerikasaan stok fisik ini dilakukan satu bulans ekali bersamaan dengan pengecekan tanggal kadaluarsa obat.

Obat yang masuk ke dalam kelompok A merupakan obat yang sering dipakai (fast moving) dengan jumlah pemakaian obat yang terbanyak. Sehingga perlu dipastikan kecukupan ketersediaan stok untuk menghindari terjadinya kekosongan yang dapat menghambat pelayanan kepada pasien di rumah sakit yang akhirnya berdampak pada kerugian bagi rumah sakit (Risdiani, 2015). Berdasarkan pengolahan data yang telah dilakukan kemudian disajikan dalam tabel 1. Pengelompokkan nilai ABC berdasarkan nilai investasi yang dapat dilihat pada tabel 2.

Tabel 1. Pengelompokkan Obat Berdasarkan Nilai Pemakaian Periode Mei 2018 - Mei 2019 Dengan Analisis ABC

\begin{tabular}{lcccc}
\hline Kelompok & $\begin{array}{c}\text { Jumlah } \\
\text { Pemakaian }\end{array}$ & $\begin{array}{c}\text { Persentase } \\
(\%)\end{array}$ & $\begin{array}{c}\text { Jumlah } \\
\text { Jenis Obat }\end{array}$ & $\begin{array}{c}\text { Persentase } \\
(\%)\end{array}$ \\
\hline A & 24.890 & 66.86 & 23 & 17.42 \\
B & 8.568 & 23.02 & 35 & 26.52 \\
C & 3.769 & 10.12 & 74 & 56.06 \\
Total & 37.227 & 100 & 132 & 100 \\
\hline
\end{tabular}

Tabel 2. Pengelompokkan Obat Berdasarkan Nilai Investasi Periode Mei 2018 - Mei 2019 Dengan Analisis $\mathrm{ABC}$

\begin{tabular}{lcccc}
\hline Kelompok & $\begin{array}{c}\text { Jumlah } \\
\text { Investasi } \\
(\mathrm{Rp})\end{array}$ & $\begin{array}{c}\text { Persentase } \\
(\%)\end{array}$ & $\begin{array}{c}\text { Jumlah } \\
\text { Jenis Obat }\end{array}$ & $\begin{array}{c}\text { Persentase } \\
(\%)\end{array}$ \\
\hline $\mathrm{A}$ & 24.454 .874 & 66.13 & 12 & 9.09 \\
$\mathrm{~B}$ & 8.579 .360 & 23.20 & 24 & 18.18 \\
$\mathrm{C}$ & 3.945 .766 & 10.67 & 96 & 72.73 \\
Total & 36.980 .000 & 100 & 132 & 100 \\
\hline
\end{tabular}

Untuk data hasil analisis $\mathrm{ABC}$ melalui nilai investasi didapatkan bahwa kelompok A menyerap investasi yang cukup tinggi. Sehingga perlu dilakukan 
pengaturan persediaan terutama agar tidak terjadi penumpukan stok karena obat-obat dengan nilai investasi tinggi menimbulkan biaya penyimpanan yang cukup tinggi. Penurunan biaya penyimpanan dengan cara dilakukannya pemesanan secara berkala dalam jumlah yang didisesuaikan dengan kebutuhan (Quict et al, 2012). Hal ini relevan dengan penelitian Humang 2018 yang menyatakan bahwa dalam menentukan jumah pemesanan harus diperhatikan biaya persediaan yang harus dikeluarkan oleh rumah sakit. Sehingga perlu diperhatikan secara berkala agar tidak terjadi stock out maupun penumpukan stok yang akhirnya rusak atau kadaluarsa.

3. Penggunaan Periode Sebelumnya

Salah satu fator penting dalam perencanaan obat adalah penggunaan periode sebelumnya (Silalahi, 1989). Perencanaan obat di Instalasi Farmasi Rumah Sakit Bedah Adelia dilakukan berdasarkan penggunaan dan pemakaian obat tiga bulan terakhir dan dengan melihat sisa stok yang ada serta anggaran yang tersedia. Tetapi belum ada perencanaan yang berfokus pada pengalokasian anggarannya, karena obat yang akan dipesan secara harian berdasarkan kebutuhan yaitu dengan melihat obat yang stoknya menipis dan obat yang dibutuhkan.

Perencanaan perbekalan farmasi merupakan proses kegiatan dalam pemilihan jenis, jumlah dan harga untuk perbekalan farmasi yang sesuai dengan kebutuhan dan anggaran sehingga menghindari kekosongan obat dengan menggunakan metode yang dapat dipertanggung jawabkan dengan menggunakan dasar-dasar perencanaan yang telah ditentukan seperti metode konsumsi, epidemiologi, kombinasi konsumsi dan epidemiologi disesuaikan dengan anggaran yang tersedia (Febriawati, 2013).

Perencanaan dan pengendalian obat di Rumah Sakit Bedah Adelia belum berjalan secara optimal dikarenakan keterbatasan SDM, sehingga perlu diterapkannya analisis ABC untuk memudahkan petugas membuat prioritas perencanaan obat.

4. Stok Pengaman dan Lead time

Stok pengaman dibutuhkan untuk menghindari kekosongan obat akibat kenaikan jumlah pemakaian. Besarnya jumlah stok pengaman dapat ditentukan berdasarkan masa tenggang atau lead time. Penetapan stok pengaman di Instalasi Farmasi Rumah Sakit Bedah Adelia dilakukan berdasarkan estimasi pemaiakan 2-4 hari.

Lead time atau masa tenggang merupakan waktu yang dibutuhkan dari mulai pemesanan obat sampai pengiriman. Lead time obat di Rumah Sakit Bedah Adelia rata-rata 1-3 hari. Masalah yang muncul bila terjadi pembelian obat dirasa cukup tinggi, maka akan ada beebrapa pesanan obat dengan pertimbangan tertentu akan dilakukan penundaan pemesanan sehingga dapat mengganggu ketersediaan obat.

5. Sistem Informasi

Manajemen yang baik dalam suatu organisasi adalah dapat memberikan fungsi dalam bidang kerjanya serta dapat menyesuaikan pelayanan dengan kebutuhan dan perubahan situasi, menjalankan sebagian pekerjaan dengan sumber daya terbatas, meningkatkan standar kualitas layanan dan mempertahankan semangat kerja staf yang tinggi (Quick et all, 2012). Sistem Informasi di Rumah Sakit Bedah Adelia masih belum menggunakan aplikasi. Sehingga jika membutuhkan data harus dilakukan secara manual.

Penataan administrasi informasi obat sangat penting terutama dengan menggunakan komputerisasi sehingga data yang diperoleh cepat untuk dipergunakan dalam perencanaan tahun berikutnya (Prisanti, 2019). Hal ini relevan dengan hasil peenlitian Wijaya, dkk (2013) bahwa aplikasi itu dapat memberikan solusi kepada perusahaan untuk menentukan jumlah pemesanan suatu barang yang optimal dan ekonomis serta memberikan solusi kepada perusahaan untuk menentukan kapan harus melakukan pemesanan kembali.

\section{Kesimpulan}

Berdasarkan analisis hasil ABC nilai pemakaian, terdapat bahwa terdapat 23 jenis obat yang masuk ke dalam kelompok A sebanyak $23(17,42 \%)$ jenis obat dengan jumlah pemakaian sebanyak 24.980 (66.68\%). Obat yang masuk ke dalam kelompok B sebanyak 35 $(26.52 \%)$ jenis obat dengan jumlah pemakaian sebanyak 8.565 (23.02\%). Sedangkan obat yang masuk ke dalam kelompok $C$ sebanyak $74(56,06 \%)$ jenis obat, dengan jumlah pemakaian sebanyak 3.769 (10,12\%) dari jumlah total pemakaian obat. Jadi dari hasil tersebut untuk kelompok A apabila terjadi kelebihan ataupun kekosongan akan menyebabkan kerugian untuk rumah sakit.

Belum adanya perencanaan obat yang memadai karena perencanaan obat hanya berdasarkan kebutuhan harian sehingga tidak ada pengalokasian anggaran. Hal ini menyebabkan jumlah pemesanan obat beberapakali tidak sesuai dengan jumlah yang seharusnya dipesan, melainkan harus disesuaikan dengan anggaran yang ada.

Sistem pencataan dan sistem yang ada belum memadai sehingga pengendalian sulit dilakukan. Pencataan data pemakaian dan data sistem informasi yang digunakan masih manual sehingga pemantauan stok obat yang ada masih belum akurat sehingga pemantauan masih berdasarkan stok fisik obat. 


\section{Daftar Pustaka}

Departemen Kesehatan RI. (2009). UU RI No 36 Tahun 2009 Tentang Kesehatan. Jakarta, Indonesia. Depastemen Kesehatan Republik Indonesia.

Febriawati, H. (2013). manajemen Logistik Farmasi Rumah Sakit. Gosyen Publishing. Yogyakarta.

Humang, R.I., \& Haerana B.T. (2018). Analisis Perencanaan Pengadaan Obat di Rumah Sakit St. Madyang Palopo Propinsi Sulawesi Selatan. Jurnal Penelitian. Stikes Mega Buana Palopo. Sulawesi Selatan

Kementrian Kesehatan RI. (2016). Permenkes RI No 72 Tahun 2016 Tentang Standar Pelayanan Kefarmasian di Rumah Sakit. jakarta, Indonesia. Kementrian Kesehatan Republik Indonesia.

Kencana, G.G. (2016). Analisis Perencanaan dan Pengendalian Obat Antibiotik di RSUD Cicalengka Tahun 2014. Jurnal Administrasi Rumah Sakit. 3(01). Universitas Indonesia. Jakarta. http://dx.doi.org/10.7454/arsi.v3i1.2211

Kindangen, G.E., Lolo, W.A., \& Citraningtyas, G. (2018). Analisis Perencanaan Pengadaan Obat Berdasarkan Metode ABC di Instalasi Farmasi RSUD Noongan Langowan. Jurnal Pharmacon 7(3). Universiats Sam Ratulangi, Manado.

Prisanti, W., Arief, K.N.P., \& Darnoto, S. (2019). Analisis Perencanaan dan Pengadaan Obat Dengan Metode Analisis ABC di Instalasi Farmasi RSIA Aisyiyah Klaten, Electronic Theses and Dissertations, Universitas Muhammadiyah Surakarta, Surakarta. http://eprints.ums.ac.id/id/eprint/77307

Quick, J.D., Rankin, Dias, \& Vimal. (2012) Inventory Management in Managing Drug Supply. Third Edition. Arlington: Management Sciences For Health.

Risdiani, I., Pribadi, F., \& Deflores, S.F.L. (2015). Analisis Perencanaan Persediaan Obat dengan Menggunakan Metode ABC Indeks Kritis di Instalasi Farmasi RSU PKU Muhammadiyah Bantul, Universitas Muhammadiyah Yogyakarta. Yogyakarta.

Seto, S., Nita, Y. \& Triana, L. (2004). Manajemen Farmasi. Airlangga University Press, Surabaya.

Silalahi, B.N.B. (1989). Prinsip Managemen Rumah Sakit. Lembaga Pengembangan Managemen Indonesia. Jakarta.

Siregar, C.J.P. (2003). Farmasi Rumah Sakit Teori dan Penerapan. EGC. Jakarta.

Suciati, S., \& Adisasmito, W.B.B. (2006). Analisis Perencanaan Obat berdasarkan Indeks Kritis di Instalasi Farmasi. Jurnal Manajemen Pelayanan Kesehatan 9(01) 19-26. Universitas Indonesia. Jakarta. 